\title{
KEPEMIMPINAN KEWIRAUSAHAAN, PEMBERDAYAAN PSIKOLOGIS, KESELAMATAN PSIKOLOGIS, DAN KREATIVITAS: STUDI PADA KARYAWAN KONSTRUKSI DI JAKARTA
}

\author{
Bimmo Dwi Baskoro ${ }^{*}$, Robby Simanjuntak ${ }^{2}$ Jayadi $^{3}$, Suherman ${ }^{4}$ \\ 1,2,3,4 Sekolah Tinggi Manajemen Labora, Jakarta, Indonesia \\ *Corresponding author: bimmodibi@gmail.com
}

\begin{abstract}
Abstrak: Tujuan penelitian ini adalah untuk meneliti pengaruh kepemimpinan kewirausahaan terhadap kreativitas karyawan melalui pemberdayaan psikologis dan keselamatan psikologis. Data diambil dari sektor konstruksi di Jakarta sebanyak 315 responden yang tergabung dalam Gapensi Jakarta. Analisis data menggunakan pendekatan SEM-PLS dengan bantuan SmartPLS versi 3.2.8. Hasil penelitian ini menemukan bahwa kepemimpinan kewirausahaan positif terkait dengan kreativitas karyawan. Selain itu, ditemukan bahwa pemberdayaan psikologis dan keselamatan psikologis memediasi hubungan antara kepemimpinan kewirausahaan dan kreativitas karyawan.
\end{abstract}

Kata kunci: kepemimpinan kewirausahaan; pemberdayaan psikologis; keselamatan psikologis; kreativitas karyawan

Abstract: The aim of this study was to investigate the effect of entrepreneurial leadership (EL) on employee creativity (EC) through psychological empowerment (PE) and psychological safety (PS). Data were taken from the construction sector in Jakarta as many as 315 respondents who joined Gapensi Jakarta. Data analysis uses the SEM-PLS approach with the help of SmartPLS 3.2.8. This study found that entrepreneurial leadership (EL) is positively related to employee creativity (EC). Psychological empowerment (PE) and psychological safety (PS) mediate the relationship between entrepreneurial leadership (EL) and employee creativity $(E C)$.

Keywords: entrepreneurial leadership (EL); psychological empowerment (PE); psychological safety (PS); employee creativity (EC)

\section{PENDAHULUAN}

Industri konstruksi dituntut untuk senantiasa melakukan inovasi dalam setiap pengerjaan proyek di lokasi. Inovasi konstruksi yang dilakukan dilakukan oleh pekerja konstruksi sesuai dengan tantangan proyek dan ekpektasi pelanggan. Teknologi informasi yang berkenaan dengan inovasi konstruksi secara langsung mempengaruhi pekerja, perusahaan, dan pelanggan. Inovasi konstruksi erat kaitannya dengan kreativitas pekerja itu sendiri yang mewakili perusahaan. Diketahui bahwa kreativitas berkaitan dengan pengembangan ide-ide inovatif dan bermanfaat di tempat kerja yang berkaitan dengan layanan, barang atau proses (Jain \& Jain, 2016). Kreativitas adalah istilah yang berbeda dari inovasi; kreativitas hanyalah penciptaan konsep baru, sementara inovasi mengacu pada penciptaan dan implementasi ide-ide tersebut (Anderson et al., 2014). Untuk semua jenis perusahaan, termasuk proyek baru atau organisasi yang ada, inovasi adalah faktor penting. Para peneliti telah mengabdikan perhatian mereka untuk menyelidiki latar 
belakang suatu inovasi (Zhou \& Hoever, 2014). Karena kepemimpinan telah dipelajari sebagai faktor kontekstual utama yang berdampak besar pada kreativitas karyawan (Qu et al., 2015), dampak dari berbagai gaya kepemimpinan terhadap kreativitas karyawan telah dikaji oleh para peneliti (Jaiswal \& Dhar, 2017; Li \& Zhang, 2016; Ma \& Jiang, 2018; Xu et al., 2017; Yang et al., 2017). Meskipun kepemimpinan transformasional telah dikatakan sebagai gaya kepemimpinan yang paling efektif untuk menciptakan kreativitas bagi karyawan, studi mengungkapkan temuan yang bertentangan tentang bagaimana kreativitas dapat ditingkatkan (Pradhan \& Jena, 2019; Tse et al., 2018). Dengan demikian, para peneliti telah memperkenalkan kepemimpinan kewirausahaan sebagai teori kepemimpinan baru yang telah muncul dari literatur tentang kepemimpinan dan kewirausahaan (Leitch \& Volery, 2017; Renko et al., 2015).

Kepemimpinan kewirausahaan menunjukkan bahwa pemimpin memiliki kompetensi untuk memotivasi dan mengarahkan pengikut untuk mencapai tujuan organisasi yang mencakup pengakuan dan eksploitasi peluang kewirausahaan (Renko et al., 2015). Dengan itu, antisipasi kegagalan dan ketidakpastian mengenai hasil upaya kreatif terdiri dari hambatan utama mencegah promosi kreativitas dalam organisasi. Organisasi-organisasi yang ambisius dan berusaha untuk memajukan kreativitas dan inovasi mereka harus mengejar pemimpin kewirausahaan yang memotivasi dan mendukung karyawan untuk secara kreatif mengenali dan mengeksploitasi peluang kewirausahaan untuk pertumbuhan bisnis (Huang et al., 2014). Namun, mekanisme bagaimana pemimpin kewirausahaan mengembangkan kreativitas karyawan belum mengeksplorasi. Oleh karena itu, tujuan inti dari penelitian saat ini adalah untuk menyelidiki dampak kepemimpinan kewirausahaan terhadap kreativitas karyawan. Mengingat bahwa para pemimpin kewirausahaan memprediksi perspektif masa depan bisnis mereka dan mengidentifikasi tujuan organisasi, di antaranya adalah pengakuan dan eksploitasi peluang (Koryak et al., 2015), harus dipahami bahwa untuk mencapai tujuan tersebut, para pemimpin kewirausahaan harus memastikan karyawan mereka bahwa mereka memiliki kemampuan kewirausahaan untuk mengeksplorasi ide-ide kreatif yang akan mengarah pada inovasi dan bahwa mereka, sebagai pemimpin, akan mendukung mereka dalam upaya mereka (Fontana \& Musa, 2017). Social learning theory (SLT) (Bandura, 1999) mengatakan bahwa karyawan belajar dari pengalaman mereka dan dengan mengamati perilaku orang lain dalam konteks interaksi sosial, dan mereka kemudian mengintegrasikan perilaku dan komponen informasi yang dipelajari ini ke dalam pemikiran dan tindakan mereka dalam situasi tertentu.

Peneliti telah menentukan bahwa kepemimpinan kewirausahaan adalah teori kepemimpinan baru, penelitian lebih lanjut diperlukan untuk memahami mekanisme kinerjanya dalam organisasi (Miao et al., 2019; Renko et al., 2015). Tujuan kedua dari penelitian ini adalah untuk menentukan mekanisme mediasi di mana para pemimpin kewirausahaan meningkatkan kreativitas karyawan. 
Penelitian terbaru menunjukkan bahwa faktor psikologis adalah pendorong utama kreativitas (Shalley \& Perry-Smith, 2001). Dalam tema yang sama, SLT juga berpendapat bahwa pikiran dan tindakan tidak selalu diantisipasi oleh pengaruh faktor kontekstual tetapi faktor-faktor psikologis itu juga memainkan peran penting, seperti yang menentukan bagaimana individu akan terpengaruh oleh pengalaman mereka dan memberikan arahan pada pemikiran dan tindakan mereka di masa depan. Dalam tema itu, pemberdayaan psikologis, yang merupakan bentuk motivasi intrinsik, telah diidentifikasi sebagai faktor penting dalam menginspirasi kreativitas pada karyawan (Zhang \& Bartol, 2010). Konsisten dengan hal ini, penelitian sebelumnya telah menemukan bahwa kepemimpinan secara positif mempengaruhi kreativitas karyawan melalui pemberdayaan psikologis (Ali Chughtai, 2016; Ma \& Jiang, 2018). Para peneliti berpendapat bahwa para pemimpin kewirausahaan membangun kepercayaan diri karyawan mereka (Harrison, Burnard, \& Paul, 2018; Renko et al., 2015). Oleh karena itu, penelitian saat ini bertujuan untuk menyelidiki efek kepemimpinan kewirausahaan terhadap kreativitas karyawan melalui pemberdayaan psikologis untuk memvalidasi kemampuan pemimpin kewirausahaan untuk meningkatkan kreativitas karyawan melalui pemberdayaan psikologis. Selain itu, tidak seperti tugas rutin dalam organisasi, kreativitas memerlukan risiko dan ketidakpastian yang mungkin menanggung konsekuensi negatif jika ide baru tidak menghasilkan hasil yang diinginkan. Dengan demikian, mengembangkan lingkungan yang aman secara psikologis sangat penting karena karyawan harus merasa aman untuk terlibat dalam kegiatan kreatif, meskipun mungkin berisiko (Wang, Liu, \& Zhu, 2018). Konsisten dengan SLT, penelitian ini mengharapkan bahwa bekerja dengan para pemimpin yang kreatif dan yang mempromosikan inovasi memungkinkan karyawan untuk merasa diberdayakan dan aman ketika berbagi dan menciptakan ide-ide baru. Oleh karena itu, menggambar di SLT, penelitian saat ini telah mengembangkan model yang mengintegrasikan kepemimpinan kewirausahaan, pemberdayaan psikologis, keselamatan psikologis, dan kreativitas karyawan. Model penelitian hipotesis disajikan pada Gambar 1.

Akhirnya, penelitian saat ini berkontribusi pada literatur yang ada dalam beberapa cara. Pertama, studi saat ini menanggapi panggilan oleh studi sebelumnya yang merekomendasikan studi lebih lanjut dilakukan untuk memvalidasi konsep teori kepemimpinan yang muncul ini di seluruh budaya dan untuk memeriksa mekanisme kinerjanya (Miao et al., 2019). Kedua, kontribusi besar dari penelitian saat ini adalah untuk meneliti peran kepemimpinan kewirausahaan yang merupakan teori kepemimpinan baru dalam merangsang kreativitas karyawan melalui keselamatan psikologis dan pemberdayaan psikologis khususnya di industri konstruksi. Dengan demikian, ini memperkaya literatur kreativitas dengan mengeksplorasi mekanisme kreativitas karyawan melalui kepemimpinan kewirausahaan dan memvalidasi pentingnya faktor psikologis dalam pengembangan kreativitas dibandingkan 
dengan studi sebelumnya, yang telah berfokus terutama pada konsep atau skala pengembangan kepemimpinan kewirausahaan (Bagheri \& Harrison, 2020; Leitch \& Volery, 2017; Renko et al., 2015). Ketiga, penelitian saat ini memvalidasi teori kepemimpinan kewirausahaan dalam organisasi yang didirikan, seperti yang disarankan oleh para penelitian terkemuka dari para pemimpin kewirausahaan yang telah mengidentifikasinya adalah teori kepemimpinan baru yang berlaku untuk ukuran apa pun dan jenis organisasi apa pun (Renko et al., 2015). Sebaliknya, para peneliti sebelumnya telah mengakui kepemimpinan kewirausahaan sebagai gaya kepemimpinan pengusaha atau berlaku dalam usaha baru dan dengan demikian memeriksa implikasinya dalam usaha baru atau usaha kecil dan menengah (Bagheri et al., 2020; Dean \& Ford, 2017; Leitch \& Volery, 2017). Orisinalitas dalam penelitian ini dapat dilihat dari

\section{METODE PENELITIAN}

\section{a. Sampel dan Prosedur}

Data diambil dari sektor konstruksi di Jakarta. Sektor konstruksi dipilih dengan mempertimbangkan aspek teknis yang memerlukan kreativitas karyawan dalam menghadapi pekerjaan di proyek. Unit analisis dalam penelitian ini adalah 1.718 perusahaan konstruksi yang tergabung dalam Asosiasi Konstruksi (Gapensi) di Jakarta. Adapun unit observasi (responden) pada penelitian ini adalah wakil perusahaan dengan jabatan minimal engineer. Dalam hal ini, perwakilan perusahaan tersebut merupakan individu yang berperan penting dalam keberhasilan proyek.

Dari jumlah 1.718 perusahaan konstruksi tersebut, terdiri dari perusahaan konstruksi dengan klasifikasi kecil sebanyak 740 perusahaan, klasifikasi menengah sebanyak 768 perusahaan, dan klasifikasi besar sebanyak 210. Penentuan sampel menggunakan pendekatan Slovin (Tejada \& Punzalan, 2012) dengan signifikansi sebesar 5 persen dan mendapat sampel sebesar 324 responden. Penelitian ini menggunakan metode random proporsional (proportional random sampling). Berdasarkan pendekatan tersebut, jumlah sampel minimal sebanyak 315 responden yang terdiri dari 140 perusahaan klasifikasi kecil, 145 perusahaan klasifikasi menengah, dan 40 perusahaan dengan klasifikasi besar. Kami mengirimkan kuesioner melalui surel kepada responden (perwakilan perusahaan) dimana sebanyak 315 responden $(97,22 \%)$ mengisi kuesioner tersebut sedangkan sebanyak 9 kusioner belum direspon dari perwakilan perusahaan klasifikasi besar. Kami menjelaskan kerahasiaan kuesioner tersebut kepada responden. Pengambilan data dilakukan selama dua bulan.

\section{b. Pengukuran}

Langkah-langkah yang digunakan dalam penelitian ini diadopsi dari studi yang ada, dan semua item diukur menggunakan skala Likert 5 poin. Skala delapan item yang dikembangkan oleh Renko et al. (2015) digunakan 
untuk mengukur kepemimpinan kewirausahaan (EL). Skala 12 item yang dikembangkan oleh Spreitzer (1995) digunakan untuk mengukur pemberdayaan psikologis (PE). Skala lima item yang dikembangkan oleh Carmeli et al. (2010) dan dimodifikasi menggunakan skala keamanan psikologis tim yang dikembangkan oleh Edmondson (1999) digunakan untuk mengukur keselamatan psikologis (PS) karyawan. Skala tiga belas item yang dikembangkan oleh Zhou \& George (2001) digunakan untuk mengukur kreativitas.

\section{c. Analisis}

Analisis statistik inferensial digunakan untuk menguji hipotesis penelitian sesuai dengan Gambar 1 adalah structural equation modelling partial least squares (SEM-PLS) dengan menggunakan perangkat lunak SmartPLS versi 3.2.8. Signifikansi yang digunakan dalam penelitian ini adalah 0,05 dan juga digunakan tes satu ekor. Pendekatan kuantitatif digunakan dalam analisis data menggunakan SPSS 22. Selain itu, analisis statistik deskriptif digunakan untuk menentukan distribusi frekuensi jawaban dan kuesioner yang diisi.

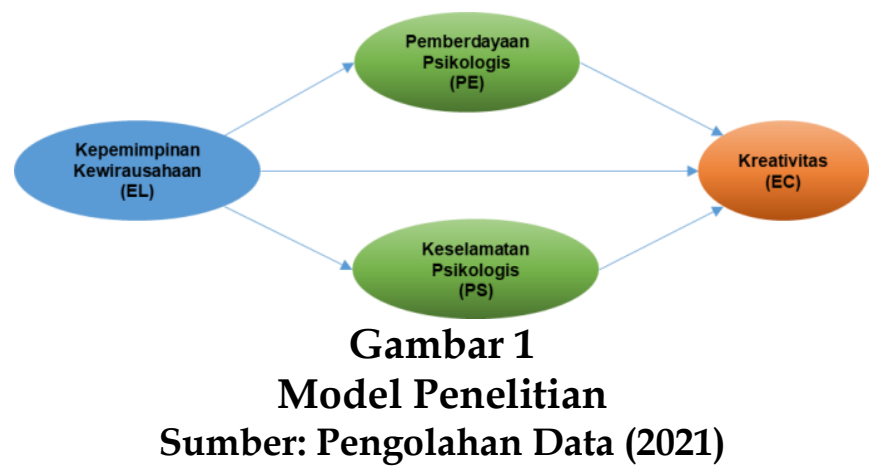

\section{HASIL DAN PEMBAHASAN}

\section{A. HASIL}

\section{Model Pengukuran}

Evaluasi model pengukuran (outer model) dilakukan untuk menentukan validitas dan keandalan yang menghubungkan indikator dengan variabel latennya. Ada tiga kriteria dalam menggunakan teknik analisis data dengan SmartPLS 3.2.8 untuk mengevaluasi outer model, yaitu convergent validity, discriminant validity, composite reliability, and average variance extracted (AVE) (Cepeda-Carrion et al., 2019; Hair et al., 2014).

Validitas konvergen pada model pengukuran dengan indikator reflektif dievaluasi berdasarkan korelasi antara skor pernyataan atau bagian yang diestimasi menggunakan perangkat lunak PLS. 
Pengukuran nilai reflektif dikatakan tinggi jika bernilai lebih dari 0,70 dari konstruk yang diukur (Hair et al., 2014). Dalam penelitian ini, batas nilai factor loading sebesar 0,70 akan digunakan. Berdasarkan analisa masih terdapat nilai factor loading dibawah 0,70 sehingga indikator tersebut harus dihapus atau dihilangkan. Dua indikator pada EL harus dihapus yakni EL1 dan EL5. Dua indikator pada PE harus dihapus yakni PE1 dan PE11. Pada konstruk PS, tidak ada indikator yang dihapus. Enam indikator pada EC harus dihapus yakni EC1, EC5, EC6, EC10, EC14, dan EC15. Hasil pemrosesan data untuk nilai faktor loading dibawah 0,70 yang sudah dihapus dapat dilihat pada Gambar 2.

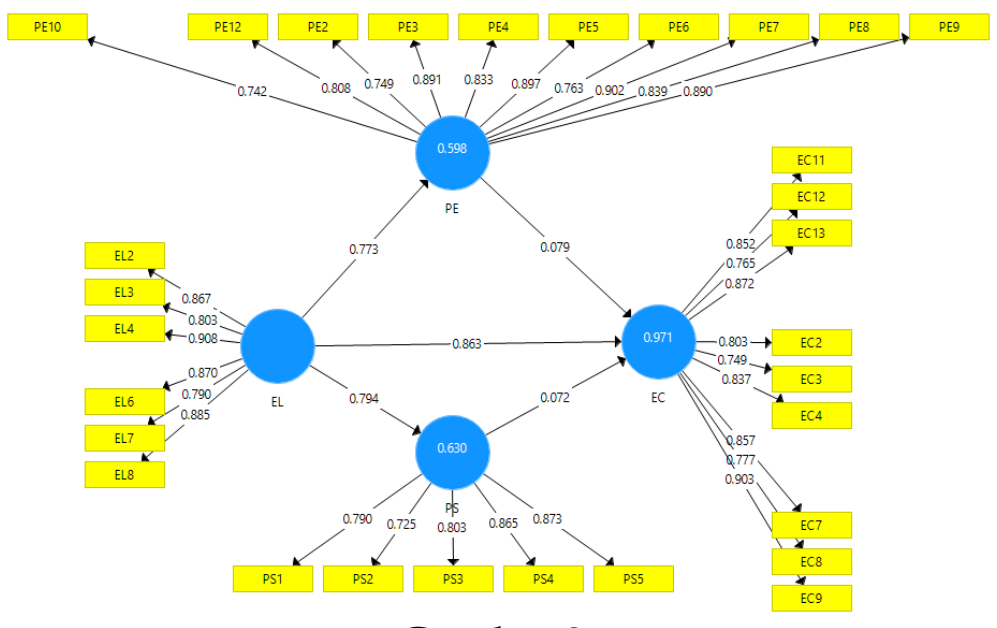

Gambar 2

Hasil Analisis Jalur PLS

Sumber: Pengolahan Data (2021)

\section{Analisis Validitas Diskriminan}

Setelah memastikan bahwa semua indikator variabel laten adalah konstruksi variabel laten, langkah selanjutnya adalah menguji validitas diskriminan. Validitas diskriminan juga perlu dilakukan agar skala yang digunakan tidak terdiri dari dua konstruk yang mengukur hal yang sama. Untuk mengetahuinya, korelasi antara konstruksi harus kurang dari 0,90. Jika antara konstruksi, korelasinya adalah 0,90 atau lebih, multikolinearitas antara konstruksi akan terjadi (Hair et al., 2014). Hasil pengujian validitas diskriminan ditunjukkan dalam Tabel 1. Seperti yang ditunjukkan dalam Tabel 1, tidak ada multikoliniaritas antara variabel karena setiap konstruksi mengukur hal-hal yang berbeda. Hal ini terbukti dari nilai korelasi antara konstruksi yang kurang dari 0,90 . 


\section{Evaluasi Reliabilitas dan AVE}

Kriteria validitas dan keandalan juga dapat dilihat dari nilai keandalan konstruk dan nilai AVE dari setiap konstruk. Konstruk dikatakan memiliki keandalan tinggi jika nilainya 0,70 dan AVE di atas 0,50 (Hair et al., 2014). Indeks composite reliability dari setiap skala semuanya lebih besar dari level 0,70 yang direkomendasikan oleh Fornell \& Larcker (1981). Tabel 1 menyajikan nilai Ca, composite reliability (CR), dan AVE untuk semua variabel.

Tabel 1

Konsistensi dan Reliabilitas

\begin{tabular}{ccccc}
\hline Konstruk & FL & Ca & CR & AVE \\
\hline EC11 & 0.852 & 0.941 & 0.95 & 0.681 \\
EC12 & 0.765 & & & \\
EC13 & 0.872 & & & \\
EC2 & 0.803 & & & \\
EC3 & 0.749 & & & \\
EC4 & 0.837 & & & \\
EC7 & 0.857 & & 0.731 \\
EC8 & 0.777 & & & \\
EC9 & 0.903 & 0.926 & & \\
EL2 & 0.867 & & & \\
EL3 & 0.803 & & & \\
EL4 & 0.908 & & & \\
EL6 & 0.870 & & & \\
EL7 & 0.790 & & & \\
EL8 & 0.885 & & & \\
PE10 & 0.742 & 0.953 & & \\
PE12 & 0.808 & & & \\
PE2 & 0.749 & & & \\
PE3 & 0.891 & & & \\
PE4 & 0.833 & & & \\
PE5 & 0.897 & & & \\
PE6 & 0.763 & & & \\
PE7 & 0.902 & & & \\
PE8 & 0.839 & & & \\
PE9 & 0.890 & & & \\
\hline PS1 & 0.790 & 0.872 & & \\
PS2 & 0.725 & & & \\
PS3 & 0.803 & & & \\
PS4 & 0.865 & & & \\
PS5 & 0.873 & & & \\
\hline Fat & & & \\
\hline FL & & & & \\
\hline
\end{tabular}

Catatan: $\mathrm{FL}=$ Factor Loading; $\mathrm{Ca}=$ Cronbach's Alpha; $\mathrm{CR}=$ Composite Reliability; $\mathrm{AVE}=$ Average Variance Extracted

Sumber: Pengolahan Data (2021)

Seperti yang ditunjukkan pada Tabel 1, EL, PE, PS, dan EC memiliki CR di atas 0,80 dan nilai Ca di atas 0,70 sehingga dapat disimpulkan bahwa indikator yang digunakan dalam setiap variabel memiliki keandalan yang baik atau dapat mengukur (Hair et al., 
2014). Namun, nilai Ca yang dihasilkan oleh PLS sedikit diremehkan sehingga disarankan untuk menggunakan nilai CR (Peterson \& Kim, 2013). Demikian juga dengan nilai AVE, variabel di atas memiliki nilai AVE di atas 0,50 sehingga dapat dikatakan bahwa setiap variabel memiliki validitas diskriminan yang tinggi.

\section{Model Struktural}

Pengujian inner model atau model struktural dilakukan untuk melihat hubungan antara konstruksi, nilai signifikansi, dan $\mathrm{R}^{2}$ dari model penelitian (Hair et al., 2019). Model struktural dievaluasi menggunakan $\mathrm{R}^{2}$ untuk konstruk yang tergantung dari uji-t serta signifikansi koefisien parameter jalur struktural. Penilaian model dengan PLS dimulai dengan melihat $\mathrm{R}^{2}$ untuk setiap variabel dependen laten. Tabel 2 memperlihatkan hasil estimasi $R^{2}$ menggunakan SmartPLS versi 3.2.8.

Tabel 2

Hasil R-Squares

\begin{tabular}{cccc}
\hline Variabel & $\boldsymbol{R}^{2}$ & $\boldsymbol{R}^{2}$ adjusted & $\boldsymbol{Q}^{2}$ \\
\hline EC & 0.971 & 0.970 & \\
PE & 0.598 & 0.597 & \multirow{2}{*}{0,995687} \\
\hline PS & 0.63 & 0.629 & \\
\hline \multicolumn{4}{c}{ Sumber: Pengolahan Data (2021) }
\end{tabular}

Tabel 2 memperlihatkan nilai $\mathrm{R}^{2}$ untuk EC yang diperoleh pada 0.971. Hasil ini menunjukkan bahwa 97,1\% EC dapat dipengaruhi oleh EL, PE, dan PS; sisanya dipengaruhi oleh variabel lain yang tidak termasuk dalam penelitian.

Nilai prediktif relevansi $\left(\mathrm{Q}^{2}\right)$ untuk model struktural dalam penelitian ini adalah 0.996 atau $99,6 \%$, artinya model tersebut mampu menjelaskan fenomena kinerja yang terkait dengan beberapa variabel, yaitu EL, PS, dan PE. Oleh karena itu, model dapat dikatakan sangat baik atau model memiliki nilai prediktif yang sangat baik. Pada akhirnya, model dapat digunakan untuk pengujian hipotesis.

\section{Uji Hipotesis}

Setelah mengetahui validitas dan keandalan item kuesioner dan mengetahui model yang dihasilkan dari analisis SEM dan kelayakan model, kami menguji hipotesis yang dikompilasi sebelumnya. Pengujian hipotesis ini didasarkan pada nilai signifikansi (nilai $\mathrm{p}$ ) < 0,05 . Jika nilai signifikansi kurang dari 0,05 , ada pengaruh antara variabel dan hipotesis yang diterima. Kami melakukan bootstrapping sebanyak 5.000 sub-sampel untuk mengukur $p$ value pada pengaruh 
langsung dan tidak langsung. Hasil pengujian hipotesis untuk efek langsung dan tidak langsung dapat dilihat pada Tabel 3 di bawah ini.

Tabel 3

Uji Hipotesis

\begin{tabular}{ccccc}
\hline Hipotesis & Hubungan & $\boldsymbol{\beta}$ & $\boldsymbol{p}$ values & Keterangan \\
\hline $\mathrm{H} 1$ & $\mathrm{EL} \rightarrow$ EC & 0,863 & 0,000 & Signifikan \\
\hline $\mathrm{H} 2$ & $\mathrm{EL} \rightarrow$ PE $\rightarrow$ EC & 0,061 & 0,007 & Signifikan \\
\hline $\mathrm{H} 3$ & $\mathrm{EL} \rightarrow$ PS $\rightarrow$ EC & 0,058 & 0,005 & Signifikan \\
\hline
\end{tabular}

Sumber: Pengolahan Data (2021)

\section{B. Pembahasan}

Kepemimpinan kewirausahaan adalah gaya kepemimpinan yang muncul yang telah berevolusi dari literatur kepemimpinan dan kewirausahaan yang ada untuk mengatasi tantangan saat ini yang dihadapi oleh organisasi (Bagheri \& Harrison, 2020). Tujuan dari penelitian saat ini adalah untuk memeriksa model terintegrasi dan hubungan antara kepemimpinan kewirausahaan, kreativitas karyawan, pemberdayaan psikologis dan keselamatan psikologis di sektor konstruksi di Jakarta. Hasil penelitian saat ini mendukung H1, yaitu, kepemimpinan kewirausahaan terkait positif dengan kreativitas karyawan. Kesimpulan ini konsisten dengan studi sebelumnya (Cai et al., 2019; Mehmood et al., 2020). Pemimpin kewirausahaan bersifat kreatif karena mereka mengembangkan visi untuk bisnis mereka yang terutama berfokus pada pengakuan dan eksploitasi peluang (Renko et al., 2015). Mereka juga mengembangkan potensi kreatif karyawan dengan menuntut partisipasi yang intens dan perubahan peran untuk memenuhi perubahan dinamis dan memotivasi karyawan melalui keterampilan komunikasi mereka (Gupta et al., 2004). Selain itu, sebagai pemimpin kewirausahaan juga berperan sebagai panutan (Renko et al., 2015), dengan mengamati dan bekerja sama dengan para pemimpin kewirausahaan, karyawan mengembangkan keterampilan kreatif mereka, seperti yang dijelaskan oleh SLT.

Demikian pula hasilnya mendukung $\mathrm{H} 2$, yaitu, kepemimpinan kewirausahaan dan kreativitas dimediasi oleh pemberdayaan psikologis. Hasil penelitian ini melengkapi temuan penelitian sebelumnya (Miao et al., 2018). Para pemimpin kewirausahaan dengan jelas mendefinisikan visi mereka dengan fokus utama pada eksplorasi peluang kewirausahaan yang harus didukung oleh karyawan mereka, dan mereka menuntut partisipasi intensif dari karyawan mereka untuk mencapai tujuan mereka (Gupta et al., 2004), keduanya berkontribusi pada persepsi karyawan bahwa pekerjaan mereka berharga bagi organisasi. Selain itu, para pemimpin kewirausahaan harus memotivasi dan mengarahkan karyawan mereka saat mereka terlibat dalam upaya 
kreatif (Harrison et al., 2018; Renko et al., 2015). Dengan demikian, para pemimpin kewirausahaan mengembangkan kepercayaan diri dan tingkat kompetensi karyawan untuk mengambil risiko dan terlibat dalam kegiatan kreatif.

Temuan ini juga mendukung H3; hasilnya mendukung temuan studi sebelumnya (Miao et al., 2019). Kreativitas adalah tugas kompleks yang melibatkan pengambilan risiko mengingat hasilnya tidak selalu sejalan dengan hasil yang diharapkan. Oleh karena itu, dukungan pemimpin adalah wajib ketika meminta karyawan untuk terlibat dalam perilaku kreatif. Yang mengatakan, pemimpin kewirausahaan memiliki kemampuan seperti itu dan mampu memastikan karyawan mereka bahwa mereka berorientasi pada kreativitas (Fontana \& Musa, 2017; Gupta et al., 2004; Harrison et al., 2018; Renko et al., 2015), yang kemudian memungkinkan karyawan untuk lebih mudah membuat dan berbagi ide-ide baru. Selain itu, temuan ini konsisten dengan peneliti SLT, yang berpendapat bahwa karyawan belajar dan mengadopsi berbagai pemikiran dan perilaku dari pengalaman langsung mereka dan melalui pengamatan dalam konteks interaksi sosial mereka. Karena interaksi ini juga mempengaruhi faktor kognitif mereka, termasuk keselamatan psikologis dan pemberdayaan psikologis, karyawan juga menggunakan informasi ini untuk mempengaruhi pikiran dan perilaku mereka.

\section{KESIMPULAN}

Berdasarkan hasil penelitian yang sudah dilakukan, kami menemukan informasi bahwa kepemimpinan kewirausahaan berpengaruh positif dan signifikan terhadap kreativitas karyawan. Lebih lanjut, efek mediasi pemberdayaan psikologis dan keamanan psikologi dalam hubungan antara kepemimpinan kewirausahaan berkorelasi positif terhadap kreativitas karyawan khususnya di sektor konstruksi di Jakarta.

\section{UCAPAN TERIMAKASIH}

Ucapan terima kasih penulis sampaikan kepada seluruh narasumber yang bersedia membantu dan memberikan informasi yang diperlukan pada penelitian ini. Ucapan terima kasih juga kami sampaikan kepada para pihak yang membantu dalam selesainya tulisan ini. 


\section{REFERENSI}

Ali Chughtai, A. (2016). Can ethical leaders enhance their followers' creativity? Leadership, 12(2), 230-249. https://doi.org/10.1177/1742715014558077

Amabile, T. (1988). A model of creativity and innovation in organizations. Research in Organizational Behavior, 10(1), 123-167.

Amabile, T. M., Conti, R., Coon, H., Lazenby, J., \& Herron, M. (1996). Assessing the Work Environment for Creativity. Academy of Management Journal, 39(5), 1154-1184. https://doi.org/10.2307/256995

Anderson, N., Potočnik, K., \& Zhou, J. (2014). Innovation and Creativity in Organizations: A State-of-the-Science Review, Prospective Commentary, and Guiding Framework. Journal of Management, 40(5), 1297-1333. https://doi.org/10.1177/0149206314527128

Ariani, N. L. P., \& Handayani, M. M. (2020). Pengaruh Inovasi Produk dan Kreativitas Pemasaran terhadap Kinerja Pemasaran: Studi pada UMKM Produk Endek di Kota Denpasar. Jurnal Manajemen Dan Bisnis Equilibrium, 6(2), 226-238. https://doi.org/10.47329/jurnal_mbe.v6i2.433

Bagheri, A. (2017). The impact of entrepreneurial leadership on innovation work behavior and opportunity recognition in high-technology SMEs. Journal of High Technology Management Research, 28(2), 159-166. https://doi.org/10.1016/j.hitech.2017.10.003

Bagheri, A., \& Harrison, C. (2020). Entrepreneurial leadership measurement: a multi-dimensional construct. Journal of Small Business and Enterprise Development, 27(4), 659-679. https:/ / doi.org/10.1108/JSBED-01-2019-0027

Bagheri, A., Newman, A., \& Eva, N. (2020). Entrepreneurial leadership of CEOs and employees' innovative behavior in high-technology new ventures. Journal of Small Business Management, 00(00), 1-23. https://doi.org/10.1080/00472778.2020.1737094

Bai, Y., Lin, L., \& Li, P. P. (2016). How to enable employee creativity in a team context: A cross-level mediating process of transformational leadership. Journal of Business Research, 69(9), 3240-3250. https://doi.org/10.1016/j.jbusres.2016.02.025

Bandura, A. (1999). Social cognitive theory: An agentic perspective. Asian Journal of Social Psychology, 2(1), 21-41. https://doi.org/10.1111/1467839X.00024 
Cai, W., Lysova, E. I., Khapova, S. N., \& Bossink, B. A. G. (2019). Does Entrepreneurial Leadership Foster Creativity Among Employees and Teams? The Mediating Role of Creative Efficacy Beliefs. Journal of Business and Psychology, 34(2), 203-217. https://doi.org/10.1007/s10869-018-9536-y

Cardon, M. S., Wincent, J., Singh, J., \& Drnovsek, M. (2009). The nature and experience of entrepreneurial passion. Academy of Management Review, 34(3), 511-532. https://doi.org/10.5465/AMR.2009.40633190

Carmeli, A., Reiter-Palmon, R., \& Ziv, E. (2010). Inclusive leadership and employee involvement in creative tasks in the workplace: The mediating role of psychological safety. Creativity Research Journal, 22(3), 250-260. https://doi.org/10.1080/10400419.2010.504654

Carmeli, A., Sheaffer, Z., Binyamin, G., Reiter-Palmon, R., \& Shimoni, T. (2014). Transformational leadership and creative problem-solving: The mediating role of psychological safety and reflexivity. Journal of Creative Behavior, 48(2), 115-135. https://doi.org/10.1002/jocb.43

Cepeda-Carrion, G., Cegarra-Navarro, J. G., \& Cillo, V. (2019). Tips to use partial least squares structural equation modelling (PLS-SEM) in knowledge management. Journal of Knowledge Management, 23(1), 67-89. https://doi.org/10.1108/JKM-05-2018-0322

Chen, A. S. Y., \& Hou, Y. H. (2016). The effects of ethical leadership, voice behavior and climates for innovation on creativity: A moderated mediation examination. Leadership Quarterly, 27(1), 1-13. https://doi.org/10.1016/j.leaqua.2015.10.007

Dean, H., \& Ford, J. (2017). Discourses of entrepreneurial leadership: Exposing myths and exploring new approaches. International Small Business Journal: Researching Entrepreneurship, 35(2), 178-196. https://doi.org/10.1177/0266242616668389

Edmondson, A. (1999). Psychological safety and learning behavior in work teams. Administrative Science Quarterly, 44(2), 350-383. https://doi.org/10.2307/2666999

Edmondson, A. C., \& Lei, Z. (2014). Psychological Safety: The History, Renaissance, and Future of an Interpersonal Construct. Annual Review of Organizational Psychology and Organizational Behavior, 1, 23-43. https://doi.org/10.1146/annurev-orgpsych-031413-091305 
Fontana, A., \& Musa, S. (2017). The impact of entrepreneurial leadership on innovation management and its measurement validation. International Journal of Innovation Science, 9(1), 2-19. https://doi.org/10.1108/IJIS-052016-0004

Fornell, C., \& Larcker, D. F. (1981). Structural Equation Models with Unobservable Variables and Measurement Error: Algebra and Statistics. Journal of Marketing Research, 18(3), 382. https:/ / doi.org/10.2307/3150980

Gagné, M., \& Deci, E. L. (2005). Self-determination theory and work motivation. Journal of Organizational Behavior, 26(4), 331-362. https://doi.org/10.1002/job.322

Gupta, V., MacMillan, I. C., \& Surie, G. (2004). Entrepreneurial leadership: Developing and measuring a cross-cultural construct. Journal of Business Venturing, 19(2), 241-260. https:/ / doi.org/10.1016/S0883-9026(03)00040-5

Hair, Joe F., Sarstedt, M., Hopkins, L., \& Kuppelwieser, V. G. (2014). Partial least squares structural equation modeling (PLS-SEM): An emerging tool in business research. European Business Review, 26(2), 106-121. https://doi.org/10.1108/EBR-10-2013-0128

Hair, Joseph F., Sarstedt, M., \& Ringle, C. M. (2019). Rethinking some of the rethinking of partial least squares. European Journal of Marketing, 53(4), 566584. https:/ / doi.org/10.1108/EJM-10-2018-0665

Harrison, C., Burnard, K., \& Paul, S. (2018). Entrepreneurial leadership in a developing economy: a skill-based analysis. Journal of Small Business and Enterprise Development, 25(3), 521-548. https://doi.org/10.1108/JSBED-052017-0160

Hemlin, S., \& Olsson, L. (2011). Creativity-Stimulating Leadership: A Critical Incident Study of Leaders' Influence on Creativity in Research Groups. Creativity and Innovation Management, 20(1), 49-58. https://doi.org/10.1111/j.1467-8691.2010.00585.x

Huang, S., Ding, D., \& Chen, Z. (2014). Entrepreneurial leadership and performance in chinese new ventures: A moderated mediation model of exploratory innovation, exploitative innovation and environmental dynamism. Creativity and Innovation Management, 23(4), 453-471. https://doi.org/10.1111/caim.12085

Jain, R., \& Jain, C. (2016). Employee Creativity: A Conceptual Framework. Management and Labour Studies, 41(4), 294-313. 
https://doi.org/10.1177/0258042×16676664

Jaiswal, N. K., \& Dhar, R. L. (2017). The influence of servant leadership, trust in leader and thriving on employee creativity. Leadership and Organization Development Journal, 38(1), 2-21. https://doi.org/10.1108/LODJ-02-20150017

Koh, D., Lee, K., \& Joshi, K. (2019). Transformational leadership and creativity: A meta-analytic review and identification of an integrated model. Journal of Organizational Behavior, 40(6), 625-650. https://doi.org/10.1002/job.2355

Koryak, O., Mole, K. F., Lockett, A., Hayton, J. C., Ucbasaran, D., \& Hodgkinson, G. P. (2015). Entrepreneurial leadership, capabilities and firm growth. International Small Business Journal: Researching Entrepreneurship, 33(1), 89-105. https:// doi.org/10.1177/0266242614558315

Leitch, C. M., \& Volery, T. (2017). Entrepreneurial leadership: Insights and directions. International Small Business Journal: Researching Entrepreneurship, 35(2), 147-156. https:/ / doi.org/10.1177/0266242616681397

Li, M., \& Zhang, P. (2016). Stimulating learning by empowering leadership: Can we achieve cross-level creativity simultaneously? Leadership and Organization Development Journal, 37(8), 1168-1186. https://doi.org/10.1108/LODJ-01-2015-0007

Liu, F., Chow, I. H. S., Zhang, J. C., \& Huang, M. (2019). Organizational innovation climate and individual innovative behavior: exploring the moderating effects of psychological ownership and psychological empowerment. Review of Managerial Science, 13(4), 771-789. https:/ / doi.org/10.1007/s11846-017-0263-y

Liu, W., Zhang, P., Liao, J., Hao, P., \& Mao, J. (2016). Abusive supervision and employee creativity: The mediating role of psychological safety and organizational identification. Management Decision, 54(1), 130-147. https:/ / doi.org/10.1108/MD-09-2013-0443

Ma, X., \& Jiang, W. (2018). Transformational Leadership, Transactional Leadership, and Employee Creativity in Entrepreneurial Firms. Journal of Applied Behavioral Science, 54(3), 302-324. https://doi.org/10.1177/0021886318764346

Maynard, M. T., Gilson, L. L., \& Mathieu, J. E. (2012). Empowerment-Fad or Fab? A Multilevel Review of the Past Two Decades of Research. Journal of Management, 38(4), 1231-1281. https:// doi.org/10.1177/0149206312438773 
Mehmood, M. S., Jian, Z., \& Akram, U. (2020). Be so creative they can't ignore you! How can entrepreneurial leader enhance the employee creativity? Thinking Skills and Creativity, 38(August), 100721. https://doi.org/10.1016/j.tsc.2020.100721

Miao, Q., Eva, N., Newman, A., \& Cooper, B. (2019). CEO Entrepreneurial Leadership and Performance Outcomes of Top Management Teams in Entrepreneurial Ventures: The Mediating Effects of Psychological Safety. Journal of Small Business Management, 57(3), 1119-1135. https://doi.org/10.1111/jsbm.12465

Miao, Q., Newman, A., Schwarz, G., \& Cooper, B. (2018). How Leadership and Public Service Motivation Enhance Innovative Behavior. Public Administration Review, 78(1), 71-81. https://doi.org/10.1111/puar.12839

Owens, B. P., \& Hekman, D. R. (2012). Modeling how to grow: An inductive examination of humble leader behaviors, contingencies, and outcomes. Academy of Management Journal, 55(4), 787-818. https://doi.org/10.5465/amj.2010.0441

Peterson, R. A., \& Kim, Y. (2013). On the relationship between coefficient alpha and composite reliability. Journal of Applied Psychology, 98(1), 194-198. https://doi.org/10.1037/a0030767

Pradhan, S., \& Jena, L. K. (2019). Does Meaningful Work Explains the Relationship Between Transformational Leadership and Innovative Work Behaviour? Vikalpa, 44(1), 30-40. https://doi.org/10.1177/0256090919832434

Qu, R., Janssen, O., \& Shi, K. (2015). Transformational leadership and follower creativity: The mediating role of follower relational identification and the moderating role of leader creativity expectations. Leadership Quarterly, 26(2), 286-299. https://doi.org/10.1016/j.leaqua.2014.12.004

Renko, M., El Tarabishy, A., Carsrud, A. L., \& Brännback, M. (2015). Understanding and measuring entrepreneurial leadership style. Journal of Small Business Management, 53(1), 54-74. https://doi.org/10.1111/jsbm.12086

Ribeiro, N., Duarte, A. P., Filipe, R., \& Torres de Oliveira, R. (2020). How Authentic Leadership Promotes Individual Creativity: The Mediating Role of Affective Commitment. Journal of Leadership and Organizational Studies, 
27(2), 189-202. https://doi.org/10.1177/1548051819842796

Shalley, C. E., \& Gilson, L. L. (2004). What leaders need to know: A review of social and contextual factors that can foster or hinder creativity. Leadership Quarterly, 15(1), 33-53. https://doi.org/10.1016/j.leaqua.2003.12.004

Shalley, C. E., \& Perry-Smith, J. E. (2001). Effects of Social-Psychological Factors on Creative Performance: The Role of Informational and Controlling Expected Evaluation and Modeling Experience. Organizational Behavior and Human Decision Processes, 84(1), 1-22. https://doi.org/10.1006/obhd.2000.2918

Spreitzer, G. M. (1995). Psychological, Empowerment in the Workplace: Dimensions, Measurement and Validation. Academy of Management Journal, 38(5), 1442-1465. https:// doi.org/10.2307/256865

Suarni, N. N., \& Sudiyani, N. N. (2020). Pengaruh Gaya Kepemimpinan dan Motivasi Kerja terhadap Kinerja Karyawan pada Kantor Camat Ubud. Jurnal Manajemen Dan Bisnis Equilibrium, 6(1), 101-108. https://doi.org/10.47329/jurnal_mbe.v6i1.414

Sumardika, I. M., \& Suwandana, I. M. A. (2019). Pengaruh Kepemimpinan Transformasional dan Disiplin Kerja terhadap Kinerja Pegawai Dinas Pemadam Kebakaran dan Penyelamatan Kabupaten Badung. Jurnal Manajemen Dan Bisnis Equilibrium, 5(2), 121-127. https://doi.org/10.47329/jurnal_mbe.v5i2.335

Sun, L. Y., Zhang, Z., Qi, J., \& Chen, Z. X. (2012). Empowerment and creativity: A cross-level investigation. Leadership Quarterly, 23(1), 55-65. https://doi.org/10.1016/j.leaqua.2011.11.005

Tejada, J., \& Punzalan, J. (2012). On the misuse of Slovin's formula. The Philippine Statistician, 61(1), 129-136.

Tse, H. H. M., To, M. L., \& Chiu, W. C. K. (2018). When and why does transformational leadership influence employee creativity? The roles of personal control and creative personality. Human Resource Management, 57(1), 145-157. https://doi.org/10.1002/hrm.21855

Wang, Y., Liu, J., \& Zhu, Y. (2018). Humble leadership, psychological safety, knowledge sharing, and follower creativity: A cross-level investigation. Frontiers in Psychology, 9(SEP). https://doi.org/10.3389/fpsyg.2018.01727 
Xu, B. Da, Zhao, S. K., Li, C. R., \& Lin, C. J. (2017). Authentic leadership and employee creativity: testing the multilevel mediation model. Leadership and Organization Development Journal, 38(3), 482-498. https://doi.org/10.1108/LODJ-09-2015-0194

Yang, J., Gu, J., \& Liu, H. (2019). Servant leadership and employee creativity: The roles of psychological empowerment and work-family conflict. Current Psychology, 38(6), 1417-1427. https://doi.org/10.1007/s12144-019-0161-3

Yang, J., Liu, H., \& Gu, J. (2017). A multi-level study of servant leadership on creativity: The roles of self-efficacy and power distance. Leadership and Organization Development Journal, 38(5), 610-629. https://doi.org/10.1108/LODJ-10-2015-0229

Yang, Y., Li, Z., Liang, L., \& Zhang, X. (2019). Why and when paradoxical leader behavior impact employee creativity: Thriving at work and psychological safety. Current Psychology. https://doi.org/10.1007/s12144018-0095-1

Yi, H., Hao, P., Yang, B., \& Liu, W. (2017). How Leaders' Transparent Behavior Influences Employee Creativity: The Mediating Roles of Psychological Safety and Ability to Focus Attention. Journal of Leadership and Organizational Studies, 24(3), 335-344. https://doi.org/10.1177/1548051816670306

Zhang, X., \& Bartol, K. M. (2010). The influence of creative process engagement on employee creative performance and overall job performance: A curvilinear assessment. Journal of Applied Psychology, 95(5), 862-873. https://doi.org/10.1037/a0020173

Zhou, J., \& George, J. M. (2001). When Job Dissatisfaction Leads to Creativity: Encouraging the Expression of Voice. Academy of Management Journal, 44(4), 682-696. https://doi.org/10.5465/3069410

Zhou, J., \& Hoever, I. J. (2014). Research on Workplace Creativity: A Review and Redirection. Annual Review of Organizational Psychology and Organizational Behavior, 1, 333-359. https://doi.org/10.1146/annurevorgpsych-031413-091226 